\title{
INVESTIGATING YOUNG LEARNERS PERCEPTION AND MORAL VALUES ON LISTENING SKILL THROUGH WATCHING MOVIE "DORA: THE LOST CITY OF GOLD"
}

\author{
Ina Rohiyatussakinah, Sri Ardiani, Ida Nuraida, Nur Hidayanti \\ Universitas Banten Jaya \\ Serang, Indonesia \\ inarohiyatussakinah@unbaja.ac.id \\ sri.ardiani.rh@gmail.com \\ idanuraida@unbaja.ac.id \\ nurhidayanti@unbja.ac.id
}

\begin{abstract}
The aim of the research was to investigate young learners perceptions and moral values on listening while English language teaching for young learner by having "Dora: The Lost Gold City" Movie at SMP Daarul Yaqiin. Method of research used descriptive analysis to explore young learner's perception and moral values. Instrument used were observation, questionnaires and interviews. Interviews and questionnaires were conducted in the seventh grades of SMP Daarul Yaqiin. It was followed by 50 young learners who join listening class. The results of this study indicate; (1) Young learners give a good perception about the use of the movie "Dora: The lost city of gold" (2) Young learners give positive feedback to attract listening skills by using the movie "Dora: The lost city of gold" in learning, and (3) young learners get moral values by watching the movie "Dora: The lost city of gold". The advantages of using the movie "Dora: The lost city of gold" in learning listening are; it helps young learners understanding the subject easily, young learners were happy, gave them motivation to learn English for young learner. From these finding the conclusion was the used of the movie "Dora: The lost city of gold" in English listening easyunderstanding material has positive response from young learners and also provided several benefits for them especially moral values for young learners.
\end{abstract}

Keyword: young learner's perception. Listening skill, movie

\section{INTRODUCTION}

Teaching English for young learners is very grateful and wonderful phase for teacher, it could have some experience learnt everything in their surroundings. The teacher has to understand the characteristics of young learners and have to manage the classroom. Then, the teacher is required to teach well and design the material of teaching learning appropriately. The material design for language teaching is the essential thing for learners' success in mastery of English. Most young learners have difficulties in pronunciation because of a lack of vocabulary; they should be taught vocabulary word by word until they pronounce correctly. Additionally, give fun activities such as games and practice or watching the video/movie. Based on the current problems, through watching the movie, young learners have experience in their learning English. TEYL for listening skill and feedback to get moral values taken from "Dora: The Lost City of Gold" as interesting movie for young learners.

Listening is a primary skill in which individuals obtain information (Barclay, 2012:4). Listening has a critical part in learning because it is one of the four major abilities in language mastery (Renukadevi, 2014:59). The other skills are reading, writing and speaking. 
The study conducted concerning the language skill evident has demonstrated that when we communicate, we gain $45 \%$ of language competence from listening, 30\% from speaking, $15 \%$ from reading, and $10 \%$ from writing. With the highest percentage of involvement in the exchange of information on effective communication, listening has to be considered a language for runner (Renukadevi, 2014:60).

Listening, not at all like the other language abilities, is feels comparatively difficult by the learners, because it has all its interrelated sub-abilities such as accepting, understanding, recalling, assessing, and respond (Renukadevi,2014:60). But with the advent of communicative language teaching and the focus on proficiency, the learning and teaching of listening started to receive more attention.

Listening is a language modality (Tyagi, 2013:1). It is one of the four abilities of a language i.e. listening, speaking, reading and writing. It includes a dynamic inclusion of a person. Listening involves a sender, a message and a recipient. It is the mental prepare of accepting, going to develop meaning of and responding to talk and/or nonverbal messages.

The process of listening occurs in five stages. They are hearing, understanding, remembering, evaluating, and responding. The process of listening will offer assistance to learners to reply to what is being asked or said. Additionally, listening is the key to all effective communication; without the capacity to listen reasonably messages are can be misconstrued, communication breaks down and the sender of the message can effectively get to be disappointed or peeved.

Listening is the most significant part of communication as it is pivotal in providing a substantial and meaningful response (Renukadevi, 2014).

The type of listening:

1. Discriminative listening is the most basic type of listening, whereby the difference between difference sounds is identified. If listener cannot hear differences, then listenercannot make sense of the meaning that is expressed by such differences.

2. Comprehensive listening is listeningfor an understanding of a message (Tyagi, 2013).

3. Extensive listening is exercises permit learners to get a part of comprehensible and pleasant listening input (Renandya, 2011:28).

This study used comprehensive listening to understanding the message. From the message of their listen, young learner get the moral value from the movie.

\section{Feedback}

$$
\text { According to Brookhart (2017:1) }
$$

Feedback defines as a basic component of the formative appraisal process. Formal assessments give information to teachers and young learners approximately how young 
learners perform relative to learning goals within the classroom. Giving great feedback is one of the skills that teachers have to be master as a portion of great formative assessment.

\section{Movie}

The movies have the impact to have a monstrous audience, in which it motivates the English foreign language learners to study new language effectively and do things so much to the public. In a study, expressed that in each day youth spends an ordinary of (6.5) hours with media because of this, it is significant to think about how youth create the messages being conveyed by the media that is imperative for adults (Yassen \& Shakir, 2015:32). The movie is one of the media in increase young learners' listening skills. Movie usage is a great help for foreign language teachers in stimulating and facilitating the target language.

\section{METHOD}

The type of research is qualitative research, and this research approach using descriptive analysis. The writer conducted the research is centered on investigating young learners' perceptions. In this research, the uncommon intrigued is the exercises of instructing and learningEnglish.

The writer watches and draws from phenomena as clear as conceivable without control. Also, the writer decided and detailed the result of investigating teaching procedures in teaching English at SMP Islam Daarul Yaqiin. The place of the study has been carried out at SMP Islam Daarul Yaqiin. With the object of the study were

Young learners of class VII consisting of 2 classes, there are class VIIA 25 young learners and class VIIB student 25 with a total of 50 young learners.

This study used data collecting procedures are questionnaire, and interview. Interview with 10 questions conducted via google form.

\section{FINDING AND DISCUSSION}

The discussion of the research obtained from the results of questionnaires, interviews, and documentation. Furthermore, it can be described as follows:

\section{The result of questionnaire}

\begin{tabular}{|c|c|c|}
\hline No & Question & percentage \\
\hline 1 & $\begin{array}{l}\text { Movie helps young } \\
\text { learners to be } \\
\text { interested in learning } \\
\text { English, especially in } \\
\text { their listening skills }\end{array}$ & $42 \%$ \\
\hline 2 & $\begin{array}{l}\text { Movie helps young } \\
\text { learners to learn social } \\
\text { and moral values that } \\
\text { are beneficial to them } \\
\text { in real life }\end{array}$ & $36 \%$ \\
\hline
\end{tabular}

3 Movie helps young $38 \%$
learners improve
critical thinking and




\begin{tabular}{|c|c|c|}
\hline \multirow[b]{2}{*}{4} & \multicolumn{2}{|l|}{ express it in English } \\
\hline & $\begin{array}{l}\text { Movie helps increase } \\
\text { young learners' } \\
\text { activeness in the } \\
\text { classroom in listening } \\
\text { skills }\end{array}$ & $40 \%$ \\
\hline & $\begin{array}{l}\text { motivate } \\
\text { learners to generate } \\
\text { interest in learning } \\
\text { English, especially in } \\
\text { listening skills }\end{array}$ & $44 \%$ \\
\hline 6 & $\begin{array}{l}\text { Movie provides an } \\
\text { interesting and fun } \\
\text { learning atmosphere }\end{array}$ & $50 \%$ \\
\hline 7 & $\begin{array}{l}\text { Movie helps young } \\
\text { learners find new } \\
\text { vocabulary }\end{array}$ & $48 \%$ \\
\hline 8 & $\begin{array}{l}\text { movie can provide } \\
\text { feedback to attract } \\
\text { young learners in } \\
\text { listening skills }\end{array}$ & $36 \%$ \\
\hline 9 & $\begin{array}{l}\text { movie can help young } \\
\text { learners understand the } \\
\text { native speakers in the } \\
\text { film }\end{array}$ & $48 \%$ \\
\hline 10 & $\begin{array}{l}\text { movie can help young } \\
\text { learners hone their } \\
\text { listening skills }\end{array}$ & $40 \%$ \\
\hline
\end{tabular}

The result of interview, The

Listen to conversations in the film.

To find out whether the use of the film

"Dora: The Lost City of Gold" can investigate young learners' perception
Interview were used to support answers from questionnaires filled out by young learners and to investigate young learners' perceptions of listening skills through watching the movie "Dora: The lost city of gold" in the pandemic era. The interview consists of 10 questions. Onestudent was still not sure about the learning model that uses a movie by watching only once. (student 5). Used movie media in listening learning student feel that the use of movie media in the listening learning process can create a class atmosphere that is more interesting, fun, not easily bored. Their perception of the use of movies in listening learning used movies as learning media, they express their happiness (student 4). In addition, movie helps them add new vocabulary (young learners 1). Therefore, they stated that the use of movies in learning helps increase listening skills.

Interviews, it can be obtained data that refers to the formulation of the problem, how to use the film "Dora: The Lost City of Gold" to determine young learners' perceptions of listening skills VII grade at SMP Daarul Yaqiin. from interview data with respondents, young learners' perceptions of watching the film "Dora: The feedback to attract their listening skills. From the questionnaire data, from 50 respondents $36 \%, 32 \%$ and $6 \%$ of young learners that watching movies can provide 
feedback to attract listening skills. To find out whether the use of the film "Dora: The Lost City of Gold" the student's film can get moral value. from the questionnaire data young learners can get social Moral values. of 50 respondents, $36 \%$ of young learners agree that films provide moral value not only to provide pleasure in learning to listen.

\section{CONCLUSION}

Based on the data obtained in this study, the authors can conclude:

1. The use of the film "Dora: The Lost City of Gold" can investigate young learners' perceptions of listening skills. young learners givea good perception of listening to listening because using movie media can help young learners listen to language conversations as well as practice their listening skills

2. The use of the film "Dora: The Lost City of Gold" can investigate young learners' perceptual feedback to draw on listening skills. from the results of the questionnaire data 50 respondents $36 \%$ young learners "strongly agree" $32 \%$ of young learners Learning Englishespecially in the ability to listen to positive responses from young learners and also gives them several advantages such as helping young learners in understand subjects easily, help them guess some unknowns and increase vocabulary.

3. The use of the film "Dora: The Lost City of Gold" can get educational value. The results of the data from the questionnaire 50 respondents $36 \%$ of young learners agreed that films can provide educational value from Dora's character who has a passion for learning and broad knowledge.

After the research was conducted, it was clear that the use of film media could be an alternative medium in teaching listening skills. Because the average data shows that most young learners agree with the use of film media in the classroom, it can be concluded that investigating young learners' perceptions of listening skills through watching the film "Dora: The Lost City of Gold" that listening skills using film media make a positive contribution to young learners' listening skills.

After getting the results of research on the use of young learners' perception of listening skills through watching movie "Dora: The lost city of gold" which gave positive results, the writer gives some suggestions, especiallyto English teachers and other parties who are interested in teaching and learning. Activities, as well as other educational elements. Here are some suggestions that thewriter can give to teacher, first the teacher needs to explore using various types of media that will be used in the teaching and learning process to young learners. In addition to using various types of media, teacher must also know how young learners feel and react whenthe media is used 
in the teaching and learning process. There, the differences in young learners' perceptions of the media used are the same. Therefore, teacher must also use

all types of media in the teaching and learning process. Furthermore, the teacher must provide and use appropriate teaching methods so that young learners can be interested in the learning process. So, young learners are encouraged to understand the subjects delivered by the teacher.

\section{REFERENCES}

Ashley, L. (2017). Research methods and methodologies in education ( $2^{\text {nd }}$ ed.). Chennai, India: Sage.

Barclay, L.A (2012). Learning to Listen/listening to Learn: Teaching Listening Skills to Young learners $\left(1^{\text {st }}\right.$ ed.).New York. NY: AFB Press.

Brookhart, S. (2017). How to give effective feedback to your young learners $\left(2^{\mathrm{n}}\right.$ ed.). Alexandria, Virginia: ASCD.

Renukadevi, D. (2014). The Role of Listening in Language Acquisition; the Challenges \& Strategies in Teaching Listening. International Journal of Education and Information Studies. ISSN 2277-3169 Volume 4, Number 1, pp. 59- 63 Research India Publications.

Renandya, W. (2011). Extensive listening in the language classroom. In $\mathrm{H}$. P. Widodo \& A. Cirocki (eds.) Innovating and creativity in ELT methodology (pp. 28-41). New York, NY: Nova science publisher.

Tyagi, B. (2013). Listening: An Important Skill and Its Various Aspects. The Criterion an International Journal in
English. Issue 12. ISSN 0976-8165.

Yaseer, B. H \& Shakir, H. (2015) Movie Effects on EFL Learners at Iraqi School in Kuala Lumpur. International Journal of Education . 